\title{
Front Matter: Volume 10190
}

, "Front Matter: Volume 10190," Proc. SPIE 10190, Ground/Air Multisensor Interoperability, Integration, and Networking for Persistent ISR VIII, 1019001 (25 May 2017); doi: 10.1117/12.2281239

SPIE. Event: SPIE Defense + Security, 2017, Anaheim, CA, United States 


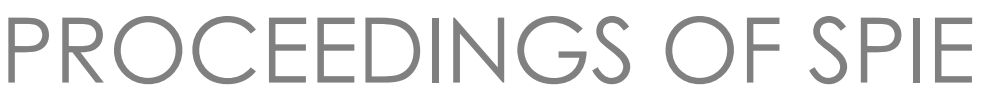

\title{
Ground/Air Multisensor Interoperability, Integration, and Networking for Persistent ISR VIII
}

\author{
Tien Pham \\ Michael A. Kolodny \\ Editors
}

10-13 April 2017

Anaheim, California, United States

Sponsored and Published by

SPIE 
The papers in this volume were part of the technical conference cited on the cover and title page. Papers were selected and subject to review by the editors and conference program committee. Some conference presentations may not be available for publication. Additional papers and presentation recordings may be available online in the SPIE Digital Library at SPIEDigitalLibrary.org.

The papers reflect the work and thoughts of the authors and are published herein as submitted. The publisher is not responsible for the validity of the information or for any outcomes resulting from reliance thereon.

Please use the following format to cite material from these proceedings:

Author(s), "Title of Paper," in Ground/Air Multisensor Interoperability, Integration, and Networking for Persistent ISR VIII, edited by Tien Pham, Michael A. Kolodny, Proceedings of SPIE Vol. 10190 (SPIE, Bellingham, WA, 2017) Seven-digit Article CID Number.

ISSN: 0277-786X

ISSN: 1996-756X (electronic)

ISBN: 9781510608818

ISBN: 9781510608825 (electronic)

Published by

SPIE

P.O. Box 10, Bellingham, Washington 98227-0010 USA

Telephone +1 3606763290 (Pacific Time) · Fax +1 3606471445

SPIE.org

Copyright (c) 2017, Society of Photo-Optical Instrumentation Engineers.

Copying of material in this book for internal or personal use, or for the internal or personal use of specific clients, beyond the fair use provisions granted by the U.S. Copyright Law is authorized by SPIE subject to payment of copying fees. The Transactional Reporting Service base fee for this volume is $\$ 18.00$ per article (or portion thereof), which should be paid directly to the Copyright Clearance Center (CCC), 222 Rosewood Drive, Danvers, MA 01923. Payment may also be made electronically through CCC Online at copyright.com. Other copying for republication, resale, advertising or promotion, or any form of systematic or multiple reproduction of any material in this book is prohibited except with permission in writing from the publisher. The CCC fee code is 0277-786X/17/\$18.00.

Printed in the United States of America.

Publication of record for individual papers is online in the SPIE Digital Library.

\section{SPIE. DIGITAL \\ SPIEDigitalLibrary.org}

Paper Numbering: Proceedings of SPIE follow an e-First publication model. A unique citation identifier (CID) number is assigned to each article at the time of publication. Utilization of CIDs allows articles to be fully citable as soon as they are published online, and connects the same identifier to all online and print versions of the publication. SPIE uses a seven-digit CID article numbering system structured as follows:

- The first five digits correspond to the SPIE volume number.

- The last two digits indicate publication order within the volume using a Base 36 numbering system employing both numerals and letters. These two-number sets start with 00, 01, 02, 03, 04, 05, 06, 07, 08, 09, OA, OB ... 0Z, followed by 10-1Z, 20-2Z, etc. The CID Number appears on each page of the manuscript. 


\title{
Contents
}

\author{
vii Authors \\ ix Conference Committee \\ xi Introduction
}

\section{SESSION 1 COALITION OPERATIONS AND INTEROPERABILITY}

1019003 ISA for the internet of tactical things [10190-2]

1019004 Interoperability at the tactical edge: lessons learned from Enterprise Challenge 2016 [10190-3]

1019005 Performing data analytics on information obtained from various sensors on an OSUS compliant system [10190-4]

1019007 Aligning vocabulary for interoperability of ISR assets using authoritative sources [10190-6]

SESSION 2 INTERNET OF THINGS (IOT) APPLICATIONS

10190 OA Coalitions of things: supporting ISR tasks via internet of things approaches [10190-9]

10190 OB Node red for sensors [10190-10]

\section{SESSION $3 \quad$ ANOMALY DETERMINATION AND DEEP LEARNING ANALYTICS}

10190 OD Deep learning on temporal-spectral data for anomaly detection [10190-12]

10190 OE A generative model for predicting terrorist incidents [10190-13]

10190 OF Discovering anomalous events from urban informatics [10190-14]

10190 OG Deep learning for anomaly detection in maritime vessels using AIS-cued camera imagery [10190-15]

$10190 \mathrm{OH}$ Framework for behavioral analytics in anomaly identification [10190-16]

SESSION 4 HUMAN-MACHINE INTERFACE AND MACHINE LEARNING APPROACHES I

$10190 \mathrm{OJ}$ The need for separate operational and engineering user interfaces for command and control of airborne synthetic aperture radar systems [10190-18] 
10190 OK Using machine learning to emulate human hearing for predictive maintenance of equipment (Keynote Paper) [10190-51]

SESSION 5 HUMAN-MACHINE INTERFACE AND MACHINE LEARNING APPROACHES II

10190 OM In-context query reformulation for failing SPARQL queries [10190-20]

$10190 \mathrm{ON}$ Interface cloning and sharing: interaction designs for conserving labor and maintaining state across $24 X 7$ sensor operations teams [10190-21]

1019000 Does this interface make my sensor look bad? Basic principles for designing usable, useful interfaces for sensor technology operators [10190-22]

\section{SESSION 6 DETECTION, TRACKING AND LOCALIZATION FOR PERSISTENT SURVEILLANCE}

$101900 Q$ Persistent maritime traffic monitoring for the Canadian Arctic [10190-24]

10190 OR Detection and localization of multiple wideband intermittent acoustic sources [10190-25]

10190 OT Track classification within wireless sensors network [10190-27]

SESSION 7 MODELING AND SIMULATION AND ENABLING TECHNOLOGIES I

$10190 \mathrm{OU}$ Sensor data fusion for automated threat recognition in manned-unmanned infantry platoons [10190-28]

10190 OV Dynamic network based learning systems for sensor information fusion [10190-29]

10190 OW Invocation oriented architecture for agile code and agile data [10190-30]

$101900 \mathrm{X}$ Heterogeneous information sharing of sensor information in contested environments [10190-32]

\section{SESSION 8 OPTIMIZATION OF UTILITY OF ISR ASSETS}

10190 OY A blockchain based architecture for asset management in coalition operations [10190-33]

$101900 Z$ Evaluating the integration of operations tasks while optimizing ISR activities [10190-34]

1019010 Mission-informed needed information: discoverable, available sensing sources (MINI-

DASS): the operators and process flows the magic rabbits must negotiate [10190-35]

SESSION 9 MODELING AND SIMULATION AND ENABLING TECHNOLOGIES II

1019014 Modeling of signal propagation and sensor performance for infrasound and blast noise [10190-39]

iv 
1019015 Photogrammetric point cloud compression for tactical networks [10190-40]

1019016 An overview of the U.S. Army Research Laboratory's Sensor Information Testbed for Collaborative Research Environment (SITCORE) and Automated Online Data Repository (AODR) capabilities [10190-41]

SESSION 10 ISR AIRBORNE IMAGING/SENSING

1019017 Distributed subterranean exploration and mapping with teams of UAVs [10190-42]

1019018 Robust drone detection for day/night counter-UAV with static VIS and SWIR cameras [10190-43]

1019019 Tree detection in urban regions from aerial imagery and DSM based on local maxima points [10190-45]

101901 A Improved hyperspectral vegetation detection using neural networks with spectral angle mapper [10190-46]

\section{SESSION 11 ISR VEHICLE STEERING/CONTROL}

$101901 \mathrm{C}$ Piezo-based, high dynamic range, wide bandwidth steering system for optical applications [10190-48]

\section{SESSION 12 ISR IMAGE PROCESSING}

10190 1D The image interpretation workstation of the future: lessons learned [10190-49] 
Proc. of SPIE Vol. $101901019001-6$

Downloaded From: https://www.spiedigitallibrary.org/conference-proceedings-of-spie on 26 Apr 2023 Terms of Use: https://www.spiedigitallibrary.org/terms-of-use 


\section{Authors}

Numbers in the index correspond to the last two digits of the seven-digit citation identifier (CID) article numbering system used in Proceedings of SPIE. The first five digits reflect the volume number. Base 36 numbering is employed for the last two digits and indicates the order of articles within the volume. Numbers start with 00, 01, 02, 03, 04, 05, 06, 07, 08, 09, 0A, 0B...0Z, followed by 10-1Z, 20-2Z, etc.

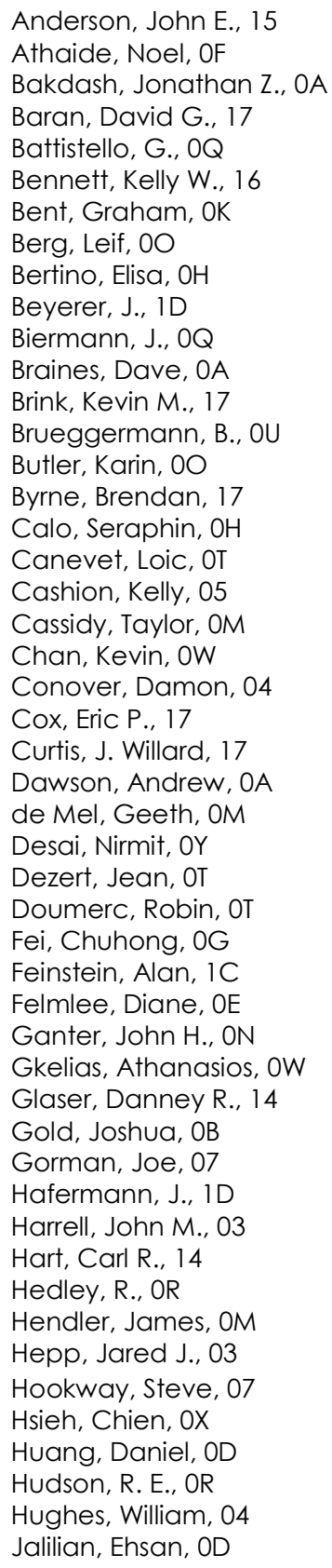

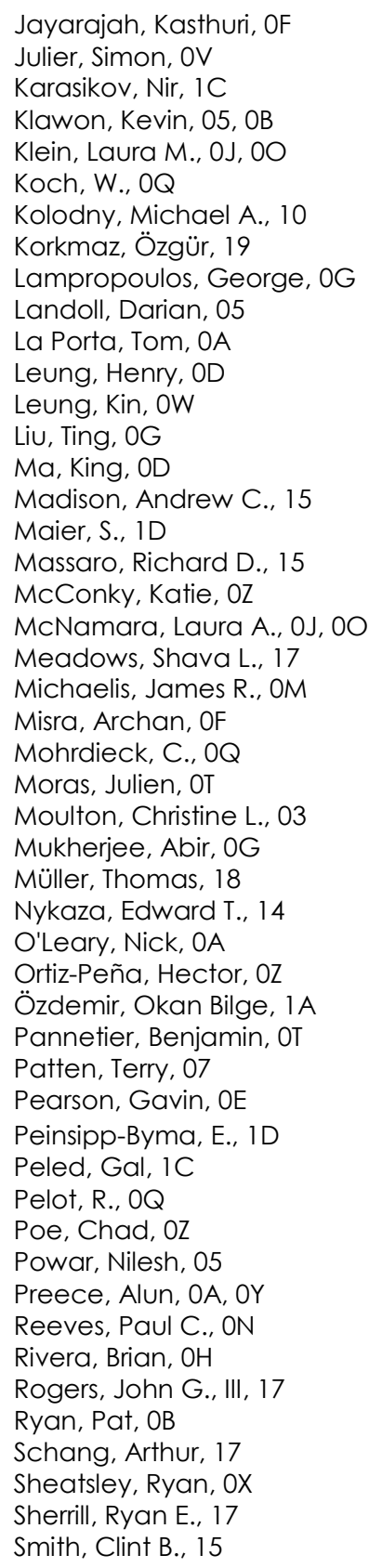


Subbaraju, Vigneshwaran, OF

Sudit, Moises, $\mathrm{OZ}$

Swearingen, Michelle E., 14

Tam, La Thanh, OF

Taylor, C. E., OR

Taylor, Ian, OA, OY

Thomas, Anna, OA

Tomsett, Richard, OA

Toth, Andrew, OX

Toth, Susan, 04

Touma, Maroun, $\mathrm{OH}$

Ulmke, M., OQ, OU

van de Camp, F., 1D

Varela, M. OU

Verma, Archit, OE

Verma, Dinesh C., OE, OH, OK, OV, OW, OY

Viswanathan, Amar, OM

Wagner, B., 1D

Waldrop, Lauren E., 14

Wampler, Jason A., OX

Ward, Dennis W., 16

Wayant, Clayton D., 15

Weerakoon, Dulanga, OF

Whitaker, Roger, OE

White, Michael J., 14

Wildt, J., OU

Wilson, D. Keith, 14

Yao, K., OR

Yardımcı Çetin, Yasemin, 19, 1A

Yasinov, Roman, 1C

Yilmaz, Erdal, 19

Zang, Yi, OG

Zaroukian, Erin, $\mathrm{OA}$ 


\section{Conference Committee}

Symposium Chair

Donald A. Reago Jr., U.S. Army Night Vision \& Electronic Sensors

Directorate (United States)

Symposium Co-chair

Arthur A. Morrish, Raytheon Space and Airborne Systems

(United States)

Conference Chairs

Tien Pham, U.S. Army Research Laboratory (United States)

Michael A. Kolodny, U.S. Army Research Laboratory (United States)

Conference Program Committee

Flavio Bergamaschi, IBM United Kingdom Ltd. (United Kingdom)

Geeth R. de Mel, IBM Thomas J. Watson Research Center

(United States)

Daniel J. Henry, Rockwell Collins, Inc. (United States)

Laura Martine Klein, Sandia National Laboratories (United States)

Laura A. McNamara, Sandia National Laboratories (United States)

Olga Mendoza-Schrock, Air Force Research Laboratory

(United States)

Gavin Pearson, Defence Science and Technology Laboratory

(United Kingdom)

King K. Siu, U.S. Army Armament Research, Development and

Engineering Center (United States)

Raja Suresh, General Dynamics Mission Systems (United States)

Igor V. Ternovskiy, Air Force Research Laboratory (United States)

Robert Williams, Air Force Research Laboratory (United States)

Dietrich M. Wiegmann, U.S. Army Research Laboratory (United States)

\section{Session Chairs}

1 Coalition Operations and Interoperability

Tien Pham, U.S. Army Research Laboratory (United States)

2 Internet of Things (IoT) Applications

Flavio Bergamaschi, IBM United Kingdom Ltd. (United Kingdom) 
3 Anomaly Determination and Deep Learning Analytics

Geeth R. de Mel, IBM Thomas J. Watson Research Center

(United States)

4 Human-machine Interface and Machine Learning Approaches I

Michael A. Kolodny, U.S. Army Research Laboratory (United States)

5 Human-machine Interface and Machine Learning Approaches II

Laura A. McNamara, Sandia National Laboratories (United States)

6 Detection, Tracking and Localization for Persistent Surveillance

Dietrich M. Wiegmann, U.S. Army Research Laboratories

(United States)

7 Modeling and Simulation and Enabling Technologies I

Tien Pham, U.S. Army Research Laboratory (United States)

8 Optimization of Utility of ISR Assets

Geeth R. de Mel, IBM Thomas J. Watson Research Center

(United States)

9 Modeling and Simulation and Enabling Technologies II

Tien Pham, U.S. Army Research Laboratory (United States)

10 ISR Airborne Imaging/Sensing

Daniel J. Henry, Rockwell Collins, Inc. (United States)

Thomas J. Walls, U.S. Naval Research Laboratory (United States)

11 ISR Vehicle Steering/Control

Daniel J. Henry, Rockwell Collins, Inc. (United States)

Thomas J. Walls, U.S. Naval Research Laboratory (United States)

12 ISR Image Processing

Thomas J. Walls, U.S. Naval Research Laboratory (United States) 


\title{
Introduction
}

This was the eighth year that Ground/Air Multisensor Interoperability, Integration, and Networking for Persistent ISR was part of the SPIE Defense and Commercial Sensing symposium. The conference was held this year from 9-13 April, in Anaheim, California. The goal of the conference is to bring together the technical, operational, (users) and policy community to provide a forum for discussion of problems, issues, and technology involving interoperability for persistent ISR. This conference focuses on promoting and advancing technology and interoperability for persistent ISR resulting in enhanced situational understanding for the warfighter decision makers!

The conference included 54 technical papers with oral presentations spread over twelve different session topics: Coalition Operations and Interoperability; Internet of Things (IOT) Applications; Anomaly Determination and Deep Learning Analytics; Human-machine Interface and Machine Learning Approaches I \& II; Detection, Tracking and Localization for Persistent Surveillance; Modeling \& Simulation and Enabling Technologies I \& II; Optimization of Utility of ISR Assets; ISR Airborne Imaging/Sensing; ISR Vehicle Steering/Control; and ISR Image Processing.

We hope you find the proceedings both provocative and informative. We are looking forward to an even more exciting conference in 2018 which will be held 15-19, April, in Orlando, Florida. We are planning some exciting events which will include a holistic and provocative panel discussion on Situational Awareness and

joint sessions with several other conferences. We hope that everyone will join us then.

\author{
Tien Pham \\ Michael A. Kolodny
}


Proc. of SPIE Vol. 10190 1019001-12 Downloaded From: https://www.spiedigitallibrary.org/conference-proceedings-of-spie on 26 Apr 2023
Terms of Use: https://www.spiedigitallibrary.org/terms-of-use 